\title{
Value of the SYNTAX score for periprocedural myocardial infarction according to WHO and the third universal definition of myocardial infarction: insights from the TWENTE trial
}

\author{
Kenneth Tandjung ${ }^{1}$, MD, PhD; Ming Kai Lam ${ }^{1}$, MD; Hanim Sen ${ }^{1}$, MD; Frits H.A.F. de Man ${ }^{1}$, MD, PhD; \\ J. (Hans) W. Louwerenburg' ${ }^{1}$, MD; Martin G. Stoel ${ }^{1}$, MD, PhD; K. Gert van Houwelingen', MD; \\ Gerard C.M. Linssen², MD, PhD; Job van der Palen ${ }^{3,4}, \mathrm{PhD}$; Carine J.M. Doggen ${ }^{5}, \mathrm{PhD}$; \\ Clemens von Birgelen ${ }^{1,5 *}, \mathrm{MD}, \mathrm{PhD}$
}

1. Department of Cardiology, Thoraxcentrum Twente, Medisch Spectrum Twente, Enschede, The Netherlands; 2. Department of Cardiology, Ziekenhuisgroep Twente, Almelo and Hengelo, The Netherlands; 3. Department of Epidemiology, Medisch Spectrum Twente, Enschede, The Netherlands; 4. Department of Research Methodology, Measurement and Data Analysis, University of Twente, Enschede, The Netherlands; 5. Department of Health Technology and Services Research, MIRA Institute for Biomedical Technology and Technical Medicine, University of Twente, Enschede, The Netherlands

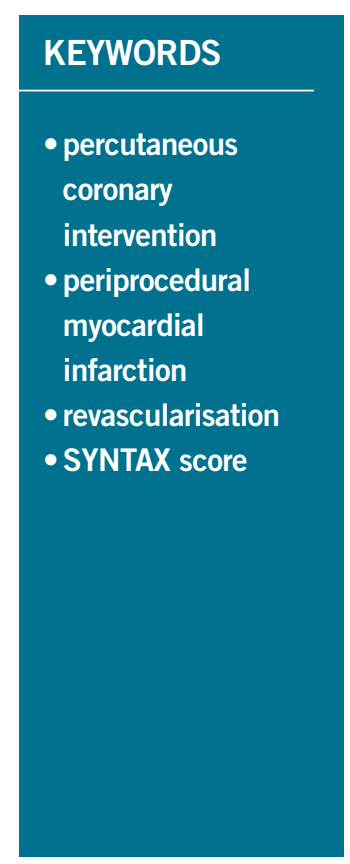

\begin{abstract}
Aims: The SYNTAX score is a tool to quantify the complexity of coronary artery disease. We investigated the relation between the SYNTAX score and the occurrence of a periprocedural myocardial infarction (PMI) according to the historical definition of the World Health Organization (WHO) and the recently updated universal definition of MI.
\end{abstract}

Methods and results: The SYNTAX score was calculated in 1,243 patients enrolled in TWENTE, a randomised trial which assessed second-generation drug-eluting stents. PMI was defined by the WHO definition and the third universal definition of MI. Patients were divided into tertiles of the SYNTAX score: $\leq 7(n=430)$; $>7$ and $<15(n=390) ; \geq 15(n=423)$. PMI according to the WHO definition occurred more frequently in patients in the highest SYNTAX score tertile $(7.3 \%$ vs. $3.1 \%$ vs. $1.6 \%, \mathrm{p}<0.001)$ compared to the mid and lowest tertile. Similar findings were seen for universal PMI (9.9\% vs. 7.7\% vs. 3.7\%, p<0.01). After multivariate analysis, SYNTAX score was a significant independent correlate of PMI for both definitions: the highest SYNTAX score tertile had an almost five times higher risk for WHO PMI, and a three times higher risk for universal PMI.

Conclusions: In a broad patient population treated with second-generation DES, the SYNTAX score was able to stratify the risk of PMI.

\footnotetext{
*Corresponding author: Department of Cardiology, Thoraxcentrum Twente, Haaksbergerstraat 55, 7513 ER Enschede, The Netherlands. E-mail: c.vonbirgelen@mst.nl
} 


$\begin{array}{ll}\text { Abbreviations } \\ \text { CABG } & \text { coronary artery bypass grafting } \\ \text { CK } & \text { creatine kinase } \\ \text { CK-MB } & \text { creatine kinase-MB } \\ \text { DES } & \text { drug-eluting stents } \\ \text { MI } & \text { myocardial infarction } \\ \text { PCI } & \text { percutaneous coronary intervention } \\ \text { PMI } & \text { periprocedural myocardial infarction } \\ \text { STEMI } & \text { ST-elevation myocardial infarction } \\ \text { WHO } & \text { World Health Organization }\end{array}$

\section{Introduction}

The SYNTAX score is a tool for the assessment of the degree and complexity of atherosclerotic disease burden of coronary arteries. It incorporates several pre-existing scoring systems such as the Leaman classification, American Heart Association/American College of Cardiology, modified BARI classification, and chronic total occlusion and bifurcation scores ${ }^{1}$.

Currently, the SYNTAX score is used mainly as a tool to evaluate the suitability of patients with multivessel disease to undergo coronary artery bypass grafting (CABG) or percutaneous coronary intervention $(\mathrm{PCI})^{2}$. In addition to this application, the SYNTAX score may also be useful to stratify the risk of periprocedural complications. Myocardial infarction after a percutaneous coronary intervention (PCI) is the most common procedural complication and is an important endpoint in coronary stent trials ${ }^{3}$. There is controversy about the clinical impact of periprocedural myocardial infarction (PMI); however, several studies have shown a relation between PMI and increased mortality ${ }^{4-6}$. So far, there are no established risk models for the prediction of PMI.

Therefore, in 1,243 real-world PCI patients from the randomised TWENTE trial ${ }^{7,8}$, treated with second-generation drugeluting stents (DES), we assessed the relation between SYNTAX score and the occurrence of PMI, as defined by the extended historical WHO definition as well as the recently updated third universal definition of MI.

\section{Methods \\ STUDY DESIGN AND PATIENT POPULATION}

The randomised TWENTE trial (ClinicalTrials.gov NCT01066650) has previously been described and reported ${ }^{7,8}$. In brief, TWENTE was an investigator-initiated, patient-blinded, randomised, comparative DES trial with limited exclusion criteria in 1,391 "realworld" PCI patients with a majority of complex lesions and off-label indications for DES. The study was performed between June 2008 and August 2010 at Thoraxcentrum Twente, Enschede, The Netherlands. Patients capable of providing informed consent with an indication for PCI with DES were randomised for treatment with Resolute ${ }^{\mathrm{TM}}$ (Medtronic, Santa Rosa, CA, USA) or XIENCE $V^{\circledR}$ stents (Abbott Vascular, Santa Clara, CA, USA) in a 1:1 ratio. There were no angiographic exclusion criteria such as a mandatory lesion length, reference vessel size, and number of target lesions or vessels. The main exclusion criterion was a recent
ST-elevation myocardial infarction (STEMI). More than $81 \%$ of the eligible patients were enrolled in this trial ${ }^{9}$.

In all trial participants, except for 148 patients with a history of CABG, SYNTAX score was prospectively assessed by analysts of the angiographic core laboratory at the Thoraxcentrum, Twente. The study was approved by the institutional ethics committee and complied with the Declaration of Helsinki. All patients provided written informed consent.

\section{DEFINITION AND ASSESSMENT OF PMI}

PMI was defined by the extended historical WHO definition (WHO PMI; total CK $>2 \mathrm{x}$ normal with elevated CK-MB or, in the case of ongoing MI, CK $>2 \mathrm{x}$ normal and $\geq 50 \%$ above the previous level if the baseline values are elevated, in addition to symptoms) and the third universal definition of MI (troponin $>5 \mathrm{x}$ normal or, in the case of ongoing MI, a rise of troponin values $>20 \%$ if the baseline values are elevated, in addition to symptoms, ECG changes, angiographic findings or new regional wall motion abnormalities) $)^{10,11}$.

In all patients, cardiac biomarkers and electrocardiograms were systematically assessed before and after index PCI or staged procedure in order to identify PMI. Cardiac biomarker measurements were scheduled before PCI and six to 18 hours after PCI, with subsequent serial measurements for relevant biomarker increases or complaints, until peak increase was established. Adjudication of WHO PMI was performed by an external clinical events committee (Cardialysis, Rotterdam, The Netherlands), and adjudication of PMI according to the universal definition of MI was performed by three experienced cardiologists/research physicians.

\section{STATISTICAL ANALYSIS}

Categorical variables were assessed with the use of the $\chi^{2}$ or Fisher's exact test, as appropriate, whereas continuous variables were assessed with the Wilcoxon rank-sum test or Student's t-test, as appropriate. Means are given with standard deviation (SD) and medians with an interquartile range (IQR). Univariate and multivariate logistic regression analyses were performed to assess the relationship between the SYNTAX score and PMI. We constructed three models: Model 1 including clinical variables with a univariate association with PMI $\mathrm{p}<0.10$; Model 2 being the full model with variables with a univariate association with PMI $\mathrm{p}<0.10$, in addition to other clinical variables used in similar research which evaluated the SYNTAX score and its relation to clinical outcome (i.e., presentation with acute coronary syndrome, age, sex, stent type, history of MI, history of PCI, and chronic renal failure $)^{12}$. In Model 3, only the SYNTAX score and the variable total stent length were entered into the model. Variables were simultaneously put into a multivariate model using the forced enter method, without exit criteria. Variables which are included in the SYNTAX score (i.e., vessel diameter, lesion length) were not included in the model to avoid collinearity. The variable left ventricular ejection fraction (LVEF) $<30 \%$ was not included in this model, as data on LVEF were not available for all patients. In order to compare SYNTAX score versus the AHA/ACC lesion classification and 
their relation to PMI, we compared the -2 log-likelihood of the full multivariate model with SYNTAX score in it with the -2 log-likelihood of the same model but with the SYNTAX score replaced by the AHA/ACC lesion classification. A higher -2 log-likelihood suggests a better model.

Unless otherwise specified, p-values and confidence intervals (CIs) were two-sided. A p-value $<0.05$ was considered significant. All statistical analyses were performed with SPSS Version 15.0 (SPSS Inc., Chicago, IL, USA).

\section{Results}

\section{SYNTAX SCORE AND BASELINE CHARACTERISTICS}

The SYNTAX score was assessed in 1,243 of the 1,391 patients $(89.4 \%)$ of the TWENTE trial who had not undergone previous CABG. The mean SYNTAX score was $12.45 \pm 8.36$, and the median
SYNTAX score was 11.00 (IQR 6.00-24.00). Based on tertiles of the SYNTAX score, the SYNTAX score was $\leq 7.0$ in 430 patients, $>7.0$ and $<15.0$ in 390 patients, and $\geq 15$ in 423 patients.

Baseline characteristics and angiographic and procedural characteristics are described in Table 1 and Table 2. Patients with the highest SYNTAX score $(\geq 15)$ were older $(p<0.001)$ and were more likely to have an LVEF $<30 \%(p=0.008)$ and a previous myocardial infarction $(\mathrm{p}<0.001)$. Post-dilation with balloon pressures $>18$ atm and use of glycoprotein IIb/IIIa antagonists were more frequent in patients with a higher SYNTAX score $(\mathrm{p}<0.001)$. Medication at discharge did not differ between groups (Table $\mathbf{3}$ ).

\section{INCIDENCE OF PMI}

The incidence of PMI according to the extended historical WHO definition and universal definition, stratified for SYNTAX

Table 1. Baseline characteristics of patients.

\begin{tabular}{|c|c|c|c|c|c|}
\hline & $\begin{array}{l}\text { Study population } \\
\qquad(n=1,243)\end{array}$ & $\begin{array}{c}\text { SYNTAX score } \leq 7.0 \\
(n=430)\end{array}$ & $\begin{array}{c}\text { SYNTAX score }>7.0 \text { and } \\
<15(n=390)\end{array}$ & $\begin{array}{l}\text { SYNTAX score } \geq 15 \\
(n=423)\end{array}$ & $\begin{array}{c}\boldsymbol{p} \text {-value across } \\
\text { groups }\end{array}$ \\
\hline Age (yrs) & $63.8(10.6)$ & $62.2(10.8)$ & $64.1(10.6)$ & $65.2(10.1)$ & $<0.01$ \\
\hline Men & $890(71.6)$ & $303(70.5)$ & $277(71.0)$ & $310(73.3)$ & 0.63 \\
\hline Body mass index $\left(\mathrm{kg} / \mathrm{m}^{2}\right)^{*}$ & $27.7(4.0)$ & $27.9(4.2)$ & $27.6(3.9)$ & $27.7(3.9)$ & 0.56 \\
\hline Diabetes mellitus & $262(21.1)$ & $89(20.7)$ & $84(21.5)$ & $89(21.0)$ & 0.96 \\
\hline Diabetes mellitus receiving insulin & $90(7.2)$ & $34(7.9)$ & $25(6.4)$ & $31(7.3)$ & 0.71 \\
\hline Chronic renal failure & $32(2.6)$ & $9(2.1)$ & $7(1.8)$ & $16(3.8)$ & 0.15 \\
\hline Arterial hypertension & $690(55.5)$ & $239(55.6)$ & $208(5.3)$ & $243(57.4)$ & 0.50 \\
\hline Hypercholesterolaemia & $700(57.8)$ & $248(58.8)$ & $216(56.8)$ & $236(57.6)$ & 0.86 \\
\hline Current smoker & $324(26.1)$ & $119(27.7)$ & $98(25.1)$ & $107(25.3)$ & 0.64 \\
\hline Family history of CAD & $651(52.4)$ & $226(52.6)$ & $204(52.3)$ & $221(52.2)$ & 1.00 \\
\hline Myocardial infarction (any) & $392(31.5)$ & $107(24.9)$ & $123(31.5)$ & $162(38.3)$ & $<0.01$ \\
\hline Previous $\mathrm{PCl}$ & $234(18.8)$ & $90(20.9)$ & 77 (19.7) & $67(15.8)$ & 0.14 \\
\hline Clinical indication & & & & & 0.24 \\
\hline Stable angina pectoris & $591(47.5)$ & $203(47.2)$ & $182(46.7)$ & $206(48.7)$ & \\
\hline Unstable angina & $285(22.9)$ & $95(22.1)$ & $104926.7)$ & $86(20.3)$ & \\
\hline Non-ST-elevation MI & $367(29.5)$ & $132(30.7)$ & $104(26.7)$ & $131(31.0)$ & \\
\hline Clinical indication: acute coronary syndrome & $652(52.5)$ & $227(52.8)$ & $208(53.3)$ & $217(51.3)$ & 0.83 \\
\hline Left ventricular ejection fraction $<30 \% \ddagger$ & $25 / 919(2.6)$ & $5 / 313(1.6)$ & 4/298 (1.3) & $16 / 313(4.9)$ & $<0.01$ \\
\hline Multivessel treatment & $293(23.6)$ & $25(5.8)$ & $99(25.4)$ & $169(40.0)$ & $<0.01$ \\
\hline Total no. of lesions treated per patient & & & & & $<0.01$ \\
\hline One lesion treated & $762(61.3)$ & $370(86.0)$ & $221(56.7)$ & $171(40.4)$ & \\
\hline Two lesions treated & $357(28.7)$ & $54(12.6)$ & $142(36.4)$ & $161(38.1)$ & \\
\hline Three or more lesions treated & $124(10.0)$ & $6(1.4)$ & $27(6.9)$ & $91(21.5)$ & \\
\hline Only de novo coronary lesions treated ${ }^{\S}$ & $60(4.8)$ & $16(3.7)$ & $27(6.9)$ & $17(4.0)$ & 0.07 \\
\hline At least one CTO treated & $83(6.7)$ & $8(1.9)$ & $17(4.4)$ & $58(13.7)$ & $<0.01$ \\
\hline At least one bifurcation treated & $337(27.1)$ & $39(9.1)$ & $107(27.4)$ & $191(45.2)$ & $<0.01$ \\
\hline At least one bifurcation with side branch treated & $199(16.0)$ & $17(4.0)$ & $69(17.7)$ & $113(26.7)$ & $<0.01$ \\
\hline At least one in-stent restenosis treated & $60(4.8)$ & $16(3.7)$ & $27(6.9)$ & $17(4.0)$ & 0.07 \\
\hline At least one small vessel (RVD <2.75 mm) & $793(63.8)$ & $231(53.7)$ & $244(62.6)$ & $318(75.2)$ & $<0.01$ \\
\hline At least one long lesion (length $>27 \mathrm{~mm}$ ) treated & $259(20.8)$ & $33(7.7)$ & $87(22.3)$ & $139(32.9)$ & $<0.01$ \\
\hline Glycoprotein IIb/Illa antagonist use & $176(14.2)$ & $37(8.6)$ & $46(11.8)$ & $93(22.0)$ & $<0.01$ \\
\hline
\end{tabular}


Table 2. Angiographic and procedural characteristics.

\begin{tabular}{|c|c|c|c|c|c|}
\hline & $\begin{array}{l}\text { Study population } \\
\quad(n=1,243)\end{array}$ & $\begin{array}{c}\text { SYNTAX score } \leq 7.0 \\
(n=430)\end{array}$ & $\begin{array}{l}\text { SYNTAX score }>7.0 \text { and } \\
\quad<15(n=390)\end{array}$ & $\begin{array}{c}\text { SYNTAX score } \geq 15 \\
(n=423)\end{array}$ & $p$-value \\
\hline \multicolumn{6}{|l|}{ Target lesion coronary artery } \\
\hline Left anterior descending & $695(55.9)$ & $143(33.3)$ & $216(55.4)$ & $336(79.4)$ & $<0.01$ \\
\hline Left circumflex & $391(31.5)$ & $133(30.9)$ & $119(30.5)$ & $139(32.9)$ & 0.74 \\
\hline Right coronary artery & $453(36.4)$ & $181(42.1)$ & $151(38.7)$ & $121(28.6)$ & $<0.01$ \\
\hline Left main & $23(1.9)$ & 0 & $9(2.3)$ & $14(3.3)$ & $<0.01$ \\
\hline Multivessel treatment & $293(23.6)$ & $25(5.8)$ & $99(25.4)$ & $169(40.0)$ & $<0.01$ \\
\hline Total lesions treated per patient & & & & & $<0.01$ \\
\hline One lesion treated & $762(61.3)$ & $370(86.0)$ & $221(56.7)$ & $171(40.4)$ & \\
\hline Two lesions treated & $357(28.7)$ & $54(12.6)$ & $142(36.4)$ & $161(38.1)$ & \\
\hline Three or more lesions treated & $124(10.0)$ & $6(1.4)$ & $27(6.9)$ & $91(21.5)$ & \\
\hline No. of stents placed & $2.02(1.18)$ & $1.38(0.69)$ & $2.00(0.97)$ & $2.68(1.38)$ & $<0.01$ \\
\hline ACC-AHA lesion class B2 or C lesion treated & $702(56.5)$ & $126(29.3)$ & $241(61.8)$ & $335(79.2)$ & $<0.01$ \\
\hline At least one ostial lesion treated & $113(9.1)$ & $28(6.5)$ & $51(13.1)$ & $34(8.0)$ & $<0.01$ \\
\hline Preprocedural TIMI flow (grade 0-1) & $99(8.0)$ & $24(5.6)$ & $35(9.0)$ & $40(9.5)$ & 0.08 \\
\hline At least one lesion directly stented & $414(33.3)$ & $196(45.6)$ & $124(31.8)$ & 94 (22.2) & $<0.01$ \\
\hline At least one stent post-dilated $>18 \mathrm{~atm}$ & $954(76.7)$ & $301(70.0)$ & $293(75.1)$ & $630(85.1)$ & $<0.01$ \\
\hline
\end{tabular}

score, is shown in Table 4. MI according to the extended historical WHO definition occurred more frequently in patients of the highest SYNTAX score tertile $(7.3 \%$ vs. $3.1 \%$ vs. $1.6 \%$, $\mathrm{p}<0.001)$ as compared to the mid and lowest SYNTAX score tertiles. In addition, PMI according to the third universal definition occurred more frequently in patients of the highest SYNTAX score tertile $(9.9 \%$ vs. $7.7 \%$ vs. $3.7 \%, p=0.002)$. The difference in definitions of PMI impacts on the diagnosis of PMI. This is shown in Figure 1.

\section{CAUSES OF PMI}

The causes of PMI are shown in Table 5. According to the extended historical WHO definition, the cause of PMI was a vessel dissection in $20 \%$, side branch occlusion in $28 \%$, no reflow in $16 \%$, and embolisation or stent thrombosis in $6 \%$. In $42 \%$, no angiographic reason was found for the occurrence of WHO PMI. For PMI according to the third universal definition, the cause of PMI was a vessel dissection in $19 \%$, side branch occlusion in $52 \%$, no reflow in $24 \%$ and embolisation or stent thrombosis

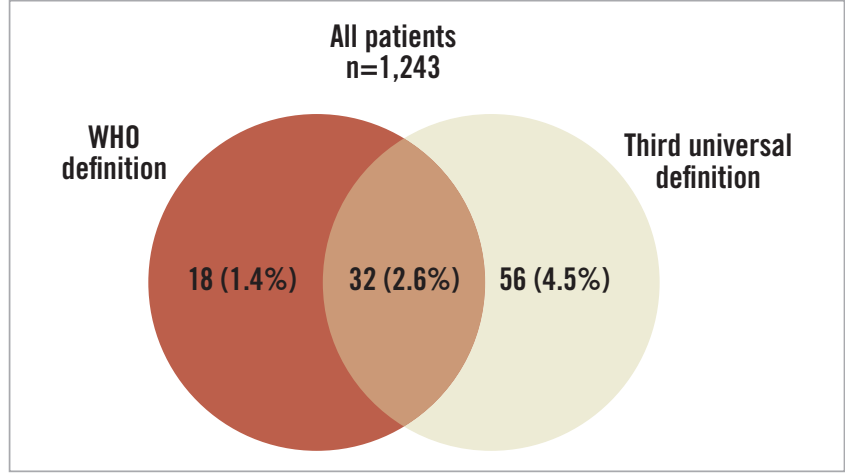

Figure 1. Venn diagram illustrating the overlap and differences of the definitions of PMI according to the WHO and third universal definition.

in $6 \%$. In $18 \%$, no angiographic reason was found for the occurrence of PMI according to the updated third universal definition. As shown, certain causes were not statistically more prevalent in higher SYNTAX scores.

Table 3. Medication at discharge.

\begin{tabular}{|c|c|c|c|c|c|c|}
\hline & & $\begin{array}{l}\text { Study population } \\
\qquad(n=1,243)\end{array}$ & $\begin{array}{c}\text { SYNTAX score } \leq 7.0 \\
(n=430)\end{array}$ & $\begin{array}{c}\text { SYNTAX score }>7.0 \text { and } \\
<15(n=390)\end{array}$ & $\begin{array}{c}\text { SYNTAX score } \geq 15 \\
(n=423)\end{array}$ & $p$-value \\
\hline \multirow[t]{2}{*}{ Antiplatelet therapy } & Acetylsalicylic acid & $1,233(99.2)$ & 426 (99.1) & 387 (99.2) & 420 (99.3) & 0.93 \\
\hline & Clopidogrel & $1,243(100)$ & $430(100)$ & $390(100)$ & $423(100)$ & 1.00 \\
\hline \multirow[t]{3}{*}{ Other medication } & Statin & $1,061(85.4)$ & $369(85.8)$ & $339(86.9)$ & $353(83.5)$ & 0.36 \\
\hline & Beta-blocker & $1,026(82.5)$ & $353(82.1)$ & $335(85.9)$ & $338(79.9)$ & 0.08 \\
\hline & ACE/ARB & $581(46.7)$ & $203(47.2)$ & 165 (42.3) & $213(50.4)$ & 0.07 \\
\hline
\end{tabular}


Table 4. The incidence of PMI according to the extended historical WHO definition and third universal definition, stratified for SYNTAX score.

\begin{tabular}{|c|c|c|c|c|c|}
\hline & $\begin{array}{l}\text { Study population } \\
\qquad(n=1,243)\end{array}$ & $\begin{array}{l}\text { SYNTAX score } \\
\leq 7.0(n=430)\end{array}$ & $\begin{array}{c}\text { SYNTAX score }>7.0 \\
\text { and }<15(n=390)\end{array}$ & $\begin{array}{c}\text { SYNTAX score } \geq 15 \\
(n=423)\end{array}$ & $p$-value \\
\hline PMI according to historical WHO definition & $50(4.0)$ & $7(1.6)$ & $12(3.1)$ & $31(7.3)$ & $<0.001$ \\
\hline PMI according to third universal definition & $88(7.1)$ & $16(3.7)$ & $30(7.7)$ & $42(9.9)$ & 0.002 \\
\hline
\end{tabular}

\section{MULTIVARIATE ANALYSIS}

Table 6 shows the complete results of the multivariate analysis. After multivariate analysis, adjusting for covariates, SYNTAX score was a significant independent predictor of PMI according to both definitions. Patients with the highest tertile of the SYNTAX score, compared to the lowest tertile, had an almost five times higher risk of PMI according to the historical WHO definition (adjusted odds ratio [OR] 4.95, 95\% confidence interval [CI]: 2.13-11.52) and an almost three times higher risk according to the updated PMI definition (adjusted OR 2.84, 95\% CI: 1.55-5.19) (Figure 2). On a continuous scale, SYNTAX score was also a significant independent predictor of PMI according to the extended

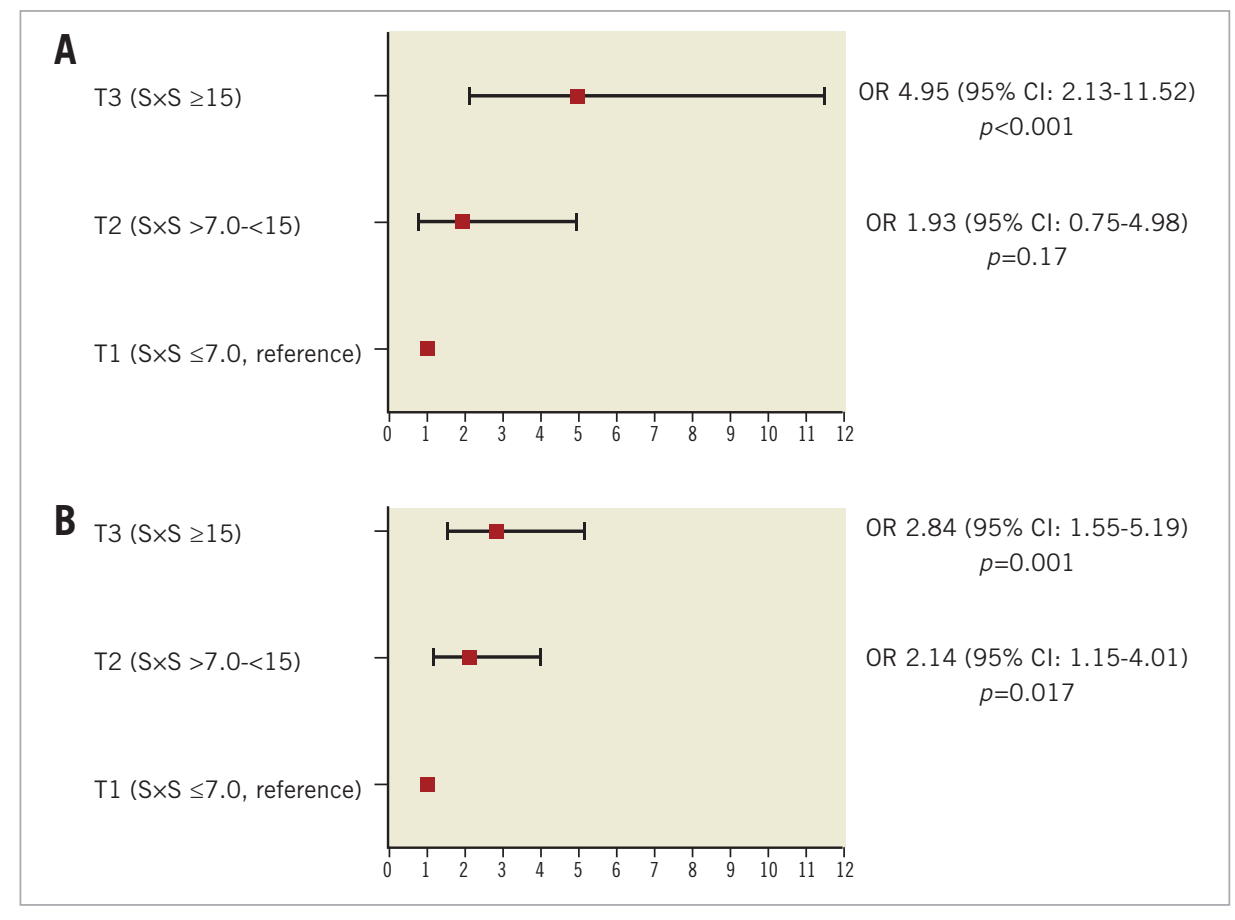

Figure 2. Multivariate adjusted odds ratios (OR) of SYNTAX score tertiles for periprocedural myocardial infarction according to the WHO definition (A), and third universal defintion of $M I(B)$.

Table 5. Causes of periprocedural myocardial infarction.

\begin{tabular}{|c|c|c|c|c|}
\hline & SYNTAX score $\leq 7.0$ & SYNTAX score $>7.0$ and $<15$ & SYNTAX score $\geq 15$ & p-value \\
\hline \multicolumn{5}{|l|}{ Cause of WHO PMI } \\
\hline Vessel dissection & $1(14.3)$ & $3(25)$ & $6(19.4)$ & 0.88 \\
\hline Side branch occlusion & $2(28.6)$ & $4(28.6)$ & $8(57.1)$ & 0.90 \\
\hline No reflow & $0(0)$ & $1(8.3)$ & 7 (22.6) & 0.33 \\
\hline Embolisation or stent thrombosis & $0(0)$ & $1(8.3)$ & $2(6.5)$ & 1.00 \\
\hline No evident cause & $4(66)$ & $6(50)$ & $11(35)$ & 0.40 \\
\hline \multicolumn{5}{|c|}{ Cause of third universal definition PMI } \\
\hline Vessel dissection & $2(12.5)$ & $5(16.7)$ & $10(23.8)$ & 0.63 \\
\hline Side branch occlusion & $8(50.0)$ & $15(50.0)$ & $23(56.1)$ & 0.85 \\
\hline No reflow & $4(25.0)$ & $6(20.0)$ & $11(26.2)$ & 0.80 \\
\hline Embolisation or stent thrombosis & $1(6.3)$ & $1(3.3)$ & $3(7.1)$ & 0.85 \\
\hline
\end{tabular}


Table 6. Univariate and multivariate analysis with both definitions of PMI.

\begin{tabular}{|c|c|c|c|c|}
\hline Clinical variable & $\begin{array}{c}\text { Odds ratio }(95 \% \mathrm{Cl}) \\
\text { WHO MI }\end{array}$ & & $\begin{array}{c}\text { Odds ratio }(95 \% \mathrm{CI}) \\
\text { Third definition } \mathrm{MI}\end{array}$ & \\
\hline \multicolumn{5}{|l|}{ SYNTAX score } \\
\hline Low SYNTAX tertile (reference) & Reference & & Reference & \\
\hline Mid SYNTAX tertile & $1.92(0.75-4.92)$ & 0.18 & $2.16(1.16-4.02)$ & 0.02 \\
\hline High SYNTAX tertile & $4.78(2.08-10.98)$ & $<0.01$ & $2.85(1.58-5.16)$ & $<0.01$ \\
\hline Age (yrs ) & $1.01(0.98-1.04)$ & 0.59 & $1.00(0.98-1.02)$ & 1.00 \\
\hline Female & $1.31(0.72-2.39)$ & 0.37 & $0.94(0.58-1.53)$ & 0.81 \\
\hline Body mass index $\left(\mathrm{kg} / \mathrm{m}^{2}\right)$ * & $1.03(0.96-1.11)$ & 0.40 & $1.05(0.99-1.11)$ & 0.11 \\
\hline Diabetes mellitus & $1.33(0.70-2.54)$ & 0.39 & $0.89(0.51-1.54)$ & 0.68 \\
\hline Diabetes mellitus receiving insulin & $2.18(0.96-4.99)$ & 0.07 & $0.93(0.40-2.20)$ & 0.87 \\
\hline Chronic renal failure" & $0.77(0.10-5.72)$ & 0.77 & $0.87(0.21-3.71)$ & 0.85 \\
\hline Arterial hypertension & $1.11(0.63-1.97)$ & 0.72 & $0.83(0.54-1.28)$ & 0.39 \\
\hline Hypercholesterolaemia & $1.19(0.65-2.16)$ & 0.58 & $1.04(0.66-1.63)$ & 0.88 \\
\hline Current smoker & $0.53(0.25-1.14)$ & 0.11 & $0.77(0.45-1.30)$ & 0.32 \\
\hline Family history of CAD & $0.77(0.43-1.35)$ & 0.36 & $1.00(0.65-1.54)$ & 0.98 \\
\hline Peripheral artery disease & $1.09(0.39-3.11)$ & 0.87 & $1.34(0.62-2.87)$ & 0.45 \\
\hline Myocardial infarction (any) & $1.23(0.68-2.22)$ & 0.49 & $1.48(0.95-2.30)$ & 0.09 \\
\hline Previous $\mathrm{PCl}$ & $1.23(0.62-2.43)$ & 0.56 & $1.12(0.65-1.92)$ & 0.69 \\
\hline \multicolumn{5}{|l|}{ Clinical indication } \\
\hline Stable angina pectoris & Reference & & Reference & \\
\hline Unstable angina & $0.71(0.33-1.53)$ & 0.38 & $1.07(0.62-1.84)$ & 0.82 \\
\hline Non-ST-elevation MI & $0.93(0.48-1.77)$ & 0.82 & $1.02(0.61-1.70)$ & 0.93 \\
\hline Clinical indication: acute coronary syndrome & $0.83(0.47-1.46)$ & 0.52 & $1.04(0.68-1.61)$ & 0.85 \\
\hline Left ventricular ejection fraction $<30 \%{ }^{\ddagger}$ & $0.89(0.12-6.76)$ & 0.91 & $0.55(0.07-4.11)$ & 0.56 \\
\hline Multivessel treatment & $2.91(1.63-5.16)$ & $<0.01$ & 1.96 (1.24-3.09) & $<0.01$ \\
\hline \multicolumn{5}{|l|}{ Total no. of lesions treated per patient } \\
\hline One lesion treated & Reference & & Reference & \\
\hline Two lesions treated & $2.77(1.42-5.41)$ & $<0.01$ & $1.75(1.06-2.87)$ & 0.03 \\
\hline Three of more lesions treated & $5.93(2.82-12.50)$ & $<0.01$ & $3.66(2.05-6.54)$ & $<0.01$ \\
\hline Only de novo coronary lesions treated ${ }^{\S}$ & $0.82(0.19-3.43)$ & 0.78 & $1.21(0.47-3.09)$ & 0.70 \\
\hline At least one CTO treated & $1.59(0.61-4.12)$ & 0.34 & $1.02(0.43-2.42)$ & 0.96 \\
\hline At least one bifurcation treated & $2.39(1.35-4.22)$ & $<0.01$ & $2.18(1.40-3.39)$ & $<0.01$ \\
\hline At least one bifurcation with side branch treated & $1.51(0.76-3.00)$ & 0.24 & $1.97(1.19-3.25)$ & $<0.01$ \\
\hline At least one in-stent restenosis treated & $0.82(0.19-3.43)$ & 0.78 & $1.21(0.47-3.09)$ & 0.70 \\
\hline At least one small vessel (RVD $<2.75 \mathrm{~mm})$ & $2.06(1.05-4.07)$ & 0.04 & $1.05(0.67-1.65)$ & 0.84 \\
\hline At least one long lesion (length $>27 \mathrm{~mm}$ ) treated & $2.91(1.63-5.19)$ & $<0.01$ & $2.60(1.65-4.10)$ & $<0.01$ \\
\hline Glycoprotein IIb/IIla antagonist use & $4.43(2.46-8.00)$ & $<0.01$ & $5.60(3.54-8.85)$ & $<0.01$ \\
\hline Stent type (XIENCE vs. Resolute [ref]) & $0.87(0.49-1.53)$ & 0.62 & $1.45(0.94-2.25$ & 0.10 \\
\hline
\end{tabular}

Multivariate Model 1. Model 1 includes the SYNTAX score as well as clinical variables with a univariate association with PMI $p<0.10$.

\begin{tabular}{|c|c|c|c|c|}
\hline Clinical variable & $\begin{array}{l}\text { Adjusted odds ratio } \\
\text { (95\% CI) WHO MI }\end{array}$ & & $\begin{array}{l}\text { Adjusted odds ratio } \\
\quad(95 \% \mathrm{CI}) \\
\text { Third definition MI }\end{array}$ & \\
\hline \multicolumn{5}{|l|}{ SYNTAX score } \\
\hline Low SYNTAX tertile (reference) & Reference & & Reference & \\
\hline Mid SYNTAX tertile & $1.95(0.76-5.01)$ & 0.17 & $2.11(1.13-3.94)$ & 0.02 \\
\hline High SYNTAX tertile & $4.80(2.08-11.09)$ & $<0.01$ & $2.74(1.51-4.97)$ & $<0.01$ \\
\hline Diabetes mellitus receiving insulin & $2.23(0.96-5.18)$ & 0.06 & $0.94(0.39-2.22)$ & 0.88 \\
\hline Myocardial infarction (any) & $1.04(0.57-1.90)$ & 0.89 & $1.35(0.86-2.11)$ & 0.18 \\
\hline
\end{tabular}


Table 6. Univariate and multivariate analysis with both definitions of PMI (cont'd).

Multivariate Model 2. Model 2 includes variables with a univariate association with PMI $p<0.10$ as well as the covariates presentation with acute coronary syndrome, age, sex, stent type, history of $\mathrm{MI}$, history of $\mathrm{PCI}$, and chronic renal failure.

\begin{tabular}{|c|c|c|c|c|}
\hline Clinical variable & $\begin{array}{l}\text { Adjusted odds ratio } \\
\text { (95\% Cl) WHO MI }\end{array}$ & & $\begin{array}{l}\text { Adjusted odds ratio } \\
\text { (95\% CI) } \\
\text { Third definition MI }\end{array}$ & \\
\hline \multicolumn{5}{|l|}{ SYNTAX score } \\
\hline Low SYNTAX tertile (reference) & Reference & & & \\
\hline Mid SYNTAX tertile & $1.93(0.75-4.98)$ & 0.17 & $2.11(1.13-3.94)$ & 0.02 \\
\hline High SYNTAX tertile & $4.95(2.13-11.52)$ & $<0.01$ & $2.84(1.55-5.19)$ & $<0.01$ \\
\hline Diabetes mellitus receiving insulin & $1.30(0.67-2.53)$ & 0.43 & $1.06(0.44-2.55)$ & 0.89 \\
\hline Myocardial infarction (any) & $1.06(0.56-2.01)$ & 0.86 & $1.31(0.81-2.13)$ & 0.28 \\
\hline Age (yrs) & $1.00(0.97-1.03)$ & 0.86 & $0.99(0.97-1.02)$ & 0.54 \\
\hline Female & $1.37(0.74-2.57)$ & 0.32 & $1.02(0.62-1.68)$ & 0.95 \\
\hline Stent type (XIENCE vs. Resolute [ref]) & $0.86(0.49-1.54)$ & 0.62 & $1.44(0.92-2.24)$ & 0.11 \\
\hline Myocardial infarction (any) & $1.06(0.56-2.02)$ & 0.86 & $1.31(0.81-2.13)$ & 0.28 \\
\hline Previous $\mathrm{PCl}$ & $1.34(0.65-2.76)$ & 0.43 & $1.06(0.60-1.89)$ & 0.84 \\
\hline Chronic renal failure & $0.60(0.08-4.64)$ & 0.63 & $0.82(0.19-3.58)$ & 0.79 \\
\hline
\end{tabular}

Multivariate Model 3. In Model 3, only the SYNTAX score and the variable stent length were entered in a multivariate model.

\begin{tabular}{|c|c|c|c|c|}
\hline Clinical variable & $\begin{array}{l}\text { Adjusted odds ratio } \\
\text { (95\% CI) WHO MI }\end{array}$ & & $\begin{array}{l}\text { Adjusted odds ratio } \\
\text { ( } 95 \% \mathrm{CI}) \\
\text { Third definition MI }\end{array}$ & \\
\hline \multicolumn{5}{|l|}{ SYNTAX score } \\
\hline Low SYNTAX tertile (reference) & Reference & & Reference & \\
\hline Mid SYNTAX tertile & $1.42(0.54-3.72)$ & 0.48 & $1.43(0.75-2.74)$ & 0.27 \\
\hline High SYNTAX tertile & $2.50(0.98-6.37)$ & 0.054 & $1.22(0.61-2.42)$ & 0.58 \\
\hline Total stent length implanted & $1.02(1.01-1.03)$ & $<0.01$ & $1.02(1.02-1.03)$ & $<0.01$ \\
\hline
\end{tabular}

historical WHO definition (adjusted OR 1.07,95\% CI: 1.04-1.10, $\mathrm{p}<0.001$ ) and the third universal definition (adjusted OR 1.04, 95\% CI: 1.01-1.06, $\mathrm{p}=0.002$ ). When total stent length implanted was entered into the multivariate model (Model 3), there was a trend that patients with the highest tertile of the SYNTAX score, compared to the lowest tertile, had a higher risk of PMI according to the WHO definition (adjusted OR 2.51, 95\% CI: 0.98-6.39, $\mathrm{p}=0.054$ ), but not according to the third definition of MI. Total stent length implanted was also a significant correlate for both definitions of PMI.

The full multivariate model with the SYNTAX score in it had a better correlation with PMI than the same model with the SYNTAX score being replaced by the AHA/ACC lesion classification (-2 log-likelihood of 407.6 versus 396.8). This suggests that the SYNTAX score is a better correlate of PMI.

\section{Discussion}

\section{MAIN FINDINGS}

The SYNTAX score is an independent correlate of PMI according to both the extended historical WHO definition ${ }^{10}$ and the recently updated universal definition of $\mathrm{MI}^{11}$. According to the historical WHO definition, patients with the highest tertile of the SYNTAX score, compared to the lowest tertile, had an almost five times higher risk of PMI (adjusted OR 4.95 [2.13-11.52]) and, according to the updated PMI definition, an almost three times higher risk (adjusted OR 2.84 [1.55-5.19]). Our data demonstrate that PCI patients with complex coronary artery disease have a higher PMI risk, and that the SYNTAX score correlated better to PMI than the AHA/ACC lesion classification. The present substudy of the TWENTE trial shows that the SYNTAX score independently predicts PMI in a large clinical trial with randomised data, external adjudication and core laboratory analysed data. These results are consistent with the findings from van Gaal et al who first described this relation in a registry ${ }^{13}$.

\section{SYNTAX SCORE AND PMI}

PMI is the most common adverse event after PCI and occurs in $5 \%$ to $30 \%$ of procedures, depending on patient population, local practice of post-procedural assessment of cardiac markers, and the diagnostic criteria applied ${ }^{14-17}$. Some studies have shown a relation between PMI and adverse outcome ${ }^{4-6}$.

In previous studies, the SYNTAX score has been shown to be associated with adverse long-term clinical outcome ${ }^{6,12,18}$; however, there are limited data on the value of the SYNTAX score on periprocedural complications in a broad population of patients undergoing PCI. 
Van Gaal et al previously assessed 100 patients with stable coronary artery disease and suggested, based on their findings in this relatively small population, that the SYNTAX score was associated with periprocedural necrosis ${ }^{13}$. Farooq et al recently reported, in a post hoc analysis of the SYNTAX trial, that a higher SYNTAX score was associated with an increased risk of PMI in 827 patients undergoing PCI with first-generation DES (TAXUS; Boston Scientific, Marlborough, MA, USA) for severe (three-vessel or left main) coronary artery disease ${ }^{6}$.

Our study population differs significantly from both of the aforementioned studies, as $10 \%$ of our patients had a history of previous CABG, 58\% presented with acute coronary syndromes, and only $24 \%$ underwent multivessel $\mathrm{PCI}^{19}$. The findings of our present study extend current knowledge by showing that, even in a broad population of contemporary PCI patients treated with second-generation DES, a higher SYNTAX score is related to an increased PMI risk.

Risk factors for PMI are associated with the burden of atherosclerotic disease (i.e., multivessel disease, calcification) and lesion complexity (i.e., thrombus formation, lesion eccentricity) ${ }^{20,21}$. These risk factors are also included in the SYNTAX score, which is a tool to assess the severity and complexity of coronary atherosclerotic disease burden. A higher SYNTAX score reflects more complex coronary artery disease, with longer lesions and/or smaller arteries which might result in higher risk for vessel dissection, side branch occlusion, no reflow or vessel occlusion causing a PMI. While numerically these causes occurred frequently in the highest SYNTAX tertile, no statistical difference was shown in the causes for PMI throughout the SYNTAX tertiles, which might have been due to the low number of events.

When the variable total stent length implanted was entered into the multivariate model, the value of the SYNTAX score as correlate for PMI was diminished, while total stent length implanted was significantly correlated with PMI. Total stent length is known to be related to lesion length, and its relation with PMI may thus be explained by the same mechanisms as previously mentioned. As the parameter lesion length is included in the SYNTAX score, collinearity may also be the reason that the value of the SYNTAX score was diminished when the variable total stent length was entered into a multivariate model.

\section{DEFINITION OF PMI}

Various clinical trials have applied different definitions of MI and PMI. In an attempt to standardise definitions, a joint European Society of Cardiology, American College of Cardiology, American Heart Association, and World Health Organization Task Force for the development of a Universal Definition of Myocardial Infarction has been established. With the development of even more sensitive assays for markers of myocardial necrosis and new insights from recent studies, the universal definition of MI has recently been updated $^{11}$ to make the definition more specific. In contrast to the second universal definition of MI, higher troponin values along with supplemental clinical information are now required in order to diagnose a PMI.
In the present study, we used the extended historical WHO definition as well as the third universal definition of MI to assess a potential relation between SYNTAX score and PMI. This relation was shown for both definitions, indicating that the relation between SYNTAX score and PMI was not related to the use of one particular definition only. Nevertheless, this relation was stronger for the WHO definition of MI, which uses a higher threshold for identifying PMI.

While several previous studies have shown a relation between PMI and short-term and long-term clinical outcome $e^{6,21}$, there is still an ongoing discussion on this issue as other studies showed no such relation ${ }^{4,22,23}$. PMI with limited marker release may have no impact on the clinical course, which recently even triggered the suggestion of a new "clinically relevant" definition of $\mathrm{PMI}^{24}$.

\section{IMPLICATIONS}

Preprocedural assessment of the SYNTAX score could help to identify patients at an increased risk of PMI, which might then trigger preventive measures. In patients with a particularly high risk of PMI, pretreatment with drugs that have anti-inflammatory and/or antithrombotic properties might be considered, such as high-dose or early initiation of statin therapy ${ }^{25,26}$, administration of a glycoprotein IIb/IIIa antagonist ${ }^{27,28}$, and perhaps even the initiation of pharmacologic treatment for glycaemic control in patients with previously unrecognised diabetes mellitus ${ }^{29}$.

\section{Limitations}

This substudy of the TWENTE trial is limited by its post hoc nature, and the findings should be considered as hypothesis-generating only. Patients undergoing primary PCI were not included in the TWENTE trial. No data on residual SYNTAX score were available in this study.

\section{Conclusion}

In a broad population of patients treated with second-generation DES, the SYNTAX score was able to stratify the risk of periprocedural myocardial infarction according to both the WHO definition and the third universal definition of myocardial infarction.

\section{Impact on daily practice}

Several studies have shown a relation between periprocedural myocardial infarction and an unfavourable outcome. The SYNTAX score may be a useful tool for risk stratification for a periprocedural myocardial infarction, and preprocedural assessment of the SYNTAX score could help to identify patients at an increased risk of PMI, which might trigger preventive measures.

\section{Funding}

The TWENTE trial is an investigator-initiated study, supported by equal unrestricted grants from Abbott Vascular and Medtronic. The research department of Thoraxcentrum Twente has received 
educational and/or research grants funded by Abbott Vascular, Biotronik, Boston Scientific, and Medtronic.

\section{Conflict of interest statement}

C. von Birgelen is a consultant to Abbott Vascular, Boston Scientific, and Medtronic; he has received a travel grant from Biotronik and lecture fees from MSD. The other authors have no conflicts of interest to declare.

\section{References}

1. Sianos G, Morel MA, Kappetein AP, Morice MC, Colombo A, Dawkins K, van den Brand M, Van Dyck N, Russell ME, Mohr FW, Serruys PW. The SYNTAX Score: an angiographic tool grading the complexity of coronary artery disease. EuroIntervention. 2005;1:219-27.

2. Mohr FW, Morice MC, Kappetein AP, Feldman TE, Stahle E, Colombo A, Mack MJ, Holmes DR Jr, Morel MA, Van Dyck N, Houle VM, Dawkins KD, Serruys PW. Coronary artery bypass graft surgery versus percutaneous coronary intervention in patients with three-vessel disease and left main coronary disease: 5-year follow-up of the randomised, clinical SYNTAX trial. Lancet. 2013;381:629-38.

3. Cutlip DE, Windecker S, Mehran R, Boam A, Cohen DJ, van Es GA, Steg PG, Morel MA, Mauri L, Vranckx P, McFadden E, Lansky A, Hamon M, Krucoff MW, Serruys PW; Academic Research Consortium. Clinical end points in coronary stent trials: a case for standardized definitions. Circulation. 2007;115:2344-51.

4. Jeremias A, Baim DS, Ho KK, Chauhan M, Carrozza JP Jr, Cohen DJ, Popma JJ, Kuntz RE, Cutlip DE. Differential mortality risk of postprocedural creatine kinase-MB elevation following successful versus unsuccessful stent procedures. $\mathrm{J} \mathrm{Am}$ Coll Cardiol. 2004;44:1210-4.

5. Prasad A, Singh M, Lerman A, Lennon RJ, Holmes DR Jr, Rihal CS. Isolated elevation in troponin $\mathrm{T}$ after percutaneous coronary intervention is associated with higher long-term mortality. J Am Coll Cardiol. 2006;48:1765-70.

6. Farooq V, Serruys PW, Vranckx P, Bourantas CV, Girasis C, Holmes DR, Kappetein AP, Mack M, Feldman T, Morice MC, Colombo A, Morel MA, de Vries T, Dawkins KD, Mohr FW, James S, Ståhle E. Incidence, correlates, and significance of abnormal cardiac enzyme rises in patients treated with surgical or percutaneous based revascularisation: a substudy from the synergy between percutaneous coronary interventions with taxus and cardiac surgery (SYNTAX) trial. Int J Cardiol. 2013;168:5287-92.

7. Basalus MW, Tandjung K, van Houwelingen KG, Stoel MG, de Man FH, Louwerenburg JW, Saïd SA, Linssen GC, Kleijne MA, van der Palen J, Huisman J, Verhorst PM, von Birgelen C. TWENTE study: The Real-World Endeavor Resolute Versus Xience V DrugEluting Stent Study in Twente: study design, rationale and objectives. Neth Heart J. 2010;18:360-4.

8. von Birgelen $\mathrm{C}$, Basalus $\mathrm{MW}$, Tandjung $\mathrm{K}$, van Houwelingen $\mathrm{KG}$, Stoel MG, Louwerenburg JH, Linssen GC, Saïd SA, Kleijne MA, Sen H, Löwik MM, van der Palen J,
Verhorst PM, de Man FH. A randomized controlled trial in secondgeneration zotarolimus-eluting Resolute stents versus everolimuseluting Xience V stents in real-world patients: the TWENTE trial. J Am Coll Cardiol. 2012;59:1350-61.

9. Sen H, Tandjung K, Basalus MW, Lowik MM, van Houwelingen GK, Stoel MG, Louwerenburg HW, de Man FH, Linssen GC, Nijhuis R, Nienhuis MB, Verhorst PM, van der Palen J, von Birgelen C. Comparison of eligible non-enrolled patients and the randomised TWENTE trial population treated with Resolute and Xience V drug-eluting stents. EuroIntervention. 2012;8:664-71.

10. Vranckx P, Cutlip DE, Mehran R, Kint PP, Silber S, Windecker S, Serruys PW. Myocardial infarction adjudication in contemporary all-comer stent trials: balancing sensitivity and specificity. Addendum to the historical MI definitions used in stent studies. EuroIntervention. 2010;5:871-4.

11. Thygesen K, Alpert JS, Jaffe AS, Simoons ML, Chaitman BR, White HD; Joint ESC/ACCF/AHA/WHF Task Force for Universal Definition of Myocardial Infarction; Authors/Task Force Members Chairpersons, Thygesen K, Alpert JS, White HD; Biomarker Subcommittee, Jaffe AS, Katus HA, Apple FS, Lindahl B, Morrow DA; ECG Subcommittee, Chaitman BR, Clemmensen PM, Johanson P, Hod H; Imaging Subcommittee, Underwood R, Bax JJ, Bonow JJ, Pinto F, Gibbons RJ; Classification Subcommittee, Fox KA, Atar D, Newby LK, Galvani M, Hamm CW; Intervention Subcommittee, Uretsky BF, Steg PG, Wijns W, Bassand JP, Menasche P, Ravkilde J; Trials \& Registries Subcommittee, Ohman EM, Antman EM, Wallentin LC, Armstrong PW, Simoons ML; Trials \& Registries Subcommittee, Januzzi JL, Nieminen MS, Gheorghiade M, Filippatos G; Trials \& Registries Subcommittee, Luepker RV, Fortmann SP, Rosamond WD, Levy D, Wood D; Trials \& Registries Subcommittee, Smith SC, Hu D, Lopez-Sendon JL, Robertson RM, Weaver D, Tendera M, Bove AA, Parkhomenko AN, Vasilieva EJ, Mendis S; ESC Committee for Practice Guidelines (CPG), Bax JJ, Baumgartner H, Ceconi C, Dean V, Deaton C, Fagard R, FunckBrentano C, Hasdai D, Hoes A, Kirchhof P, Knuuti J, Kolh P, McDonagh T, Moulin C, Popescu BA, Reiner Z, Sechtem U, Sirnes PA, Tendera M, Torbicki A, Vahanian A, Windecker S; Document Reviewers, Morais J, Aguiar C, Almahmeed W, Arnar DO, Barili F, Bloch KD, Bolger AF, Botker HE, Bozkurt B, Bugiardini R, Cannon C, de Lemos J, Eberli FR, Escobar E, Hlatky M, James S, Kern KB, Moliterno DJ, Mueller C, Neskovic AN, Pieske BM, Schulman SP, Storey RF, Taubert KA, Vranckx P, Wagner DR. Third universal definition of myocardial infarction. J Am Coll Cardiol. 2012;60:1581-98.

12. Wykrzykowska JJ, Garg S, Girasis C, de Vries T, Morel MA, van Es GA, Buszman P, Linke A, Ischinger T, Klauss V, Corti R, Eberli F, Wijns W, Morice MC, di Mario C, van Geuns RJ, Juni P, Windecker S, Serruys PW. Value of the SYNTAX score for risk assessment in the all-comers population of the randomized multicenter LEADERS (Limus Eluted from A Durable versus ERodable Stent coating) trial. J Am Coll Cardiol. 2010;56:272-7. 
13. van Gaal WJ, Ponnuthurai FA, Selvanayagam J, Testa L, Porto I, Neubauer S, Banning AP. The Syntax score predicts periprocedural myocardial necrosis during percutaneous coronary intervention. Int J Cardiol. 2009;135:60-5.

14. Babu GG, Walker JM, Yellon DM, Hausenloy DJ. Periprocedural myocardial injury during percutaneous coronary intervention: an important target for cardioprotection. Eur Heart J. 2011;32:23-31.

15. Kedhi E, Joesoef KS, McFadden E, Wassing J, van Mieghem C, Goedhart D, Smits PC. Second-generation everolimus-eluting and paclitaxel-eluting stents in real-life practice (COMPARE): a randomised trial. Lancet. 2010;375:201-9.

16. Prasad A, Herrmann J. Myocardial infarction due to percutaneous coronary intervention. N Engl J Med. 2011;364:453-64.

17. Testa L, Van Gaal WJ, Biondi Zoccai GG, Agostoni P, Latini RA, Bedogni F, Porto I, Banning AP. Myocardial infarction after percutaneous coronary intervention: a meta-analysis of troponin elevation applying the new universal definition. QJM. 2009;102:369-78.

18. Garg S, Serruys PW, Silber S, Wykrzykowska J, van Geuns RJ, Richardt G, Buszman PE, Kelbæk H, van Boven AJ, Hofma SH, Linke A, Klauss V, Wijns W, Macaya C, Garot P, DiMario C, Manoharan G, Kornowski R, Ischinger T, Bartorelli A, Van Remortel E, Ronden J, Windecker S. The prognostic utility of the SYNTAX score on 1-year outcomes after revascularization with zotarolimus- and everolimus-eluting stents: a substudy of the RESOLUTE All Comers Trial. JACC Cardiovasc Interv. 2011;4:432-41.

19. Tandjung K, Sen H, Lam MK, Basalus MW, Louwerenburg JH, Stoel MG, van Houwelingen KG, de Man FH, Linssen GC, Saïd SA, Nienhuis MB, Löwik MM, Verhorst PM, van der Palen J, von Birgelen C. Clinical outcome following stringent discontinuation of dual antiplatelet therapy after 12 months in real-world patients treated with second-generation zotarolimus-eluting resolute and everolimus-eluting Xience V stents: 2-year follow-up of the randomized TWENTE trial. J Am Coll Cardiol. 2013;61:2406-16.

20. Lansky AJ, Stone GW. Periprocedural myocardial infarction: prevalence, prognosis, and prevention. Circ Cardiovasc Interv. 2010;3:602-10.

21. Tandjung K, Basalus MW, Muurman E, Louwerenburg HW, van Houwelingen KG, Stoel MG, de Man FH, Jansen H, Huisman J, Linssen GC, Droste HT, Nienhuis MB, von Birgelen C. Incidence of periprocedural myocardial infarction following stent implantation: comparison between first- and second-generation drug-eluting stents. Catheter Cardiovasc Interv. 2012;80:524-30.

22. Pervaiz MH, Sood P, Sudhir K, Hermiller JB, Hou L, Hattori K, Su X, Cao S, Wang J, Applegate RJ, Kereiakes DJ, Yaqub M, Stone GW, Cutlip DE. Periprocedural myocardial infarction in a randomized trial of everolimus-eluting and paclitaxel-eluting coronary stents: frequency and impact on mortality according to historic versus universal definitions. Circ Cardiovasc Interv. 2012;5:150-6.

23. Prasad A, Gersh BJ, Bertrand ME, Lincoff AM, Moses JW, Ohman EM, White HD, Pocock SJ, McLaurin BT, Cox DA, Lansky AJ, Mehran R, Stone GW. Prognostic significance of periprocedural versus spontaneously occurring myocardial infarction after percutaneous coronary intervention in patients with acute coronary syndromes: an analysis from the ACUITY (Acute Catheterization and Urgent Intervention Triage Strategy) trial. $J \mathrm{Am}$ Coll Cardiol. 2009;54:477-86.

24. Moussa ID, Klein LW, Shah B, Mehran R, Mack MJ, Brilakis ES, Reilly JP, Zoghbi G, Holper E, Stone GW. Consideration of a new definition of clinically relevant myocardial infarction after coronary revascularization: an expert consensus document from the Society for Cardiovascular Angiography and Interventions (SCAI). J Am Coll Cardiol. 2013;62:1563-70.

25. Di Sciascio G, Patti G, Pasceri V, Gaspardone A, Colonna G, Montinaro A. Efficacy of atorvastatin reload in patients on chronic statin therapy undergoing percutaneous coronary intervention: results of the ARMYDA-RECAPTURE (Atorvastatin for Reduction of Myocardial Damage During Angioplasty) Randomized Trial. J Am Coll Cardiol. 2009;54:558-65.

26. Otagiri K, Tsutsui H, Kumazaki S, Miyashita Y, Aizawa K, Koshikawa M, Kasai H, Izawa A, Tomita T, Koyama J, Ikeda U.

Early intervention with rosuvastatin decreases the lipid components of the plaque in acute coronary syndrome: analysis using integrated backscatter IVUS (ELAN study). Circ J. 2011;75:633-41.

27. Cohen M, Ferguson JJ. Re-evaluating risk factors for periprocedural complications during percutaneous coronary intervention in patients with unstable angina/non-ST-elevation myocardial infarction: who may benefit from more intensive antiplatelet therapy? Curr Opin Cardiol. 2009;24:88-94.

28. Patti G, Pasceri V, D'Antonio L, D'Ambrosio A, Macri M, Dicuonzo G, Colonna G, Montinaro A, Di Sciascio G. Comparison of safety and efficacy of bivalirudin versus unfractionated heparin in high-risk patients undergoing percutaneous coronary intervention (from the Anti-Thrombotic Strategy for Reduction of Myocardial Damage During Angioplasty-Bivalirudin vs Heparin study). Am J Cardiol. 2012;110:478-84.

29. Tandjung K, van Houwelingen KG, Jansen H, Basalus MW, Sen H, Löwik MM, Stoel MG, Louwerenburg JH, de Man FH, Linssen GC, Nijhuis R, Nienhuis MB, van der Palen J, Stolk RP, von Birgelen C. Comparison of frequency of periprocedural myocardial infarction in patients with and without diabetes mellitus to those with previously unknown but elevated glycated hemoglobin levels (from the TWENTE trial). Am J Cardiol. 2012;110:1561-7. 